\title{
Rotor syndrome
}

INSERM

\section{Source}

INSERM. (1999). Orphanet: an online rare disease and orphan drug data base. Rotor syndrome. ORPHA:3111

Rotor syndrome (RT) is a benign, inherited liver disorder characterized by chronic, predominantly conjug ated, nonhemolytic hyperbilirubinemia with normal liver histology. 